\title{
Forest Voices: Competing Narratives over REDD+
}

\author{
Rocío Hiraldo and Thomas Tanner
}

\begin{abstract}
The Reducing Emissions from Deforestation and Forest Degradation (known collectively as REDD+) initiative has emerged as a means through which individuals, projects and communities in developing countries can be financially rewarded for reducing emissions from deforestation, forest degradation and enhancement of carbon stock. In this article, we analyse the various framings and actor coalitions around REDD+ and institutional dynamics within the conceptualisation and development of REDD+. We conclude with a reflection on the key aspects for the political economy of REDD+ under a post-Kyoto agreement, arguing that increased institutional recognition and support to less powerful forest voices is needed if equity rights as social justice are to be considered as key aspects of the future global climate change regime.
\end{abstract}

\section{Introduction}

The Reducing Emissions from Deforestation and Forest Degradation (known collectively as REDD+) initiative has emerged as a means through which individuals, projects and communities in developing countries can be financially rewarded for reducing emissions from deforestation, forest degradation and enhancement of carbon stock (UNFGCG 2009). The creation of REDD+ is now linked to the recent introduction and acceptance of forestry actions in the post-2012 climate regime under the United Nations Framework Convention on Climate Change (UNFCGG) (Angelsen and Atmadja 2008). This responds to the lack of incentives for taking action to reduce or avoid emissions in forestry in developing countries experiencing or at risk of large-scale deforestation (Santilli et al. 2005).

In this article, we will analyse how the various actors contributing to the design of global REDD+ architecture have different and sometimes contradictory political goals and enjoy different degrees of social, economic and political capital and power (Bourdieu 1986). We argue that a political economy approach helps us understand how REDD+ structures are being established as this framework draws on the actors, ideas and interests that are competing and converging in REDD + . In the next section, we introduce the history of REDD + negotiations with a focus on the major contentions. We then identify key actors and ideological drivers in REDD + . We conclude with a reflection on the key aspects for the political economy of REDD+ under a post-Kyoto agreement.

\section{Developing REDD+: History of negotiations and key issues}

Since the idea of REDD+ came to the global arena, there has been much debate on how this mechanism should be designed and implemented. Actors converging come from a wide range of institutions including national governments, intergovernmental organisations, multilateral as well as private financial institutions, environmental organisations, research institutes and indigenous organisations (UNFCCG $2011 \mathrm{a}$ ). All of them are intervening with different proposals for REDD+ implementation, leading to the creation of clusters around particular interests and hence reinforcing competition.

\subsection{From RED to REDD+}

While the idea of reducing emissions from deforestation and forest degradation became formalised at the UNFCCG 13th Conference of the Parties (COP13) in 2007 (UNFCGC 2007), the seeds for REDD+ initiative were planted during negotiation of the Kyoto Protocol in 1997 (Figure 1), where 'the role of forests as carbon sinks, the 


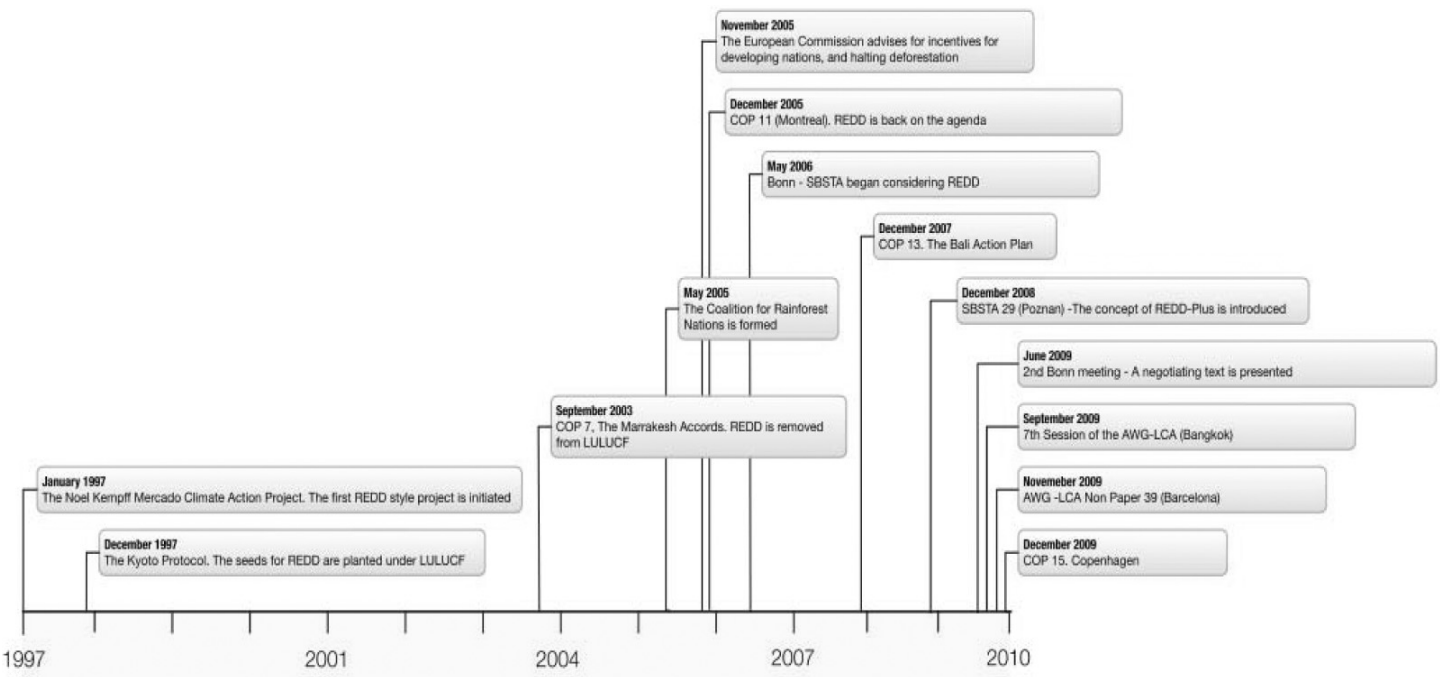

Source Holloway and Giandomenico (2009: 4); reproduced with kind permission of Carbon Planet Limited and the authors.

sustainable use of agricultural land and the promotion of sustainable forest management practices, afforestation and restoration' were recognised (UNFCGC 1997: 2). However, mitigation strategies under the Kyoto Protocol had focused mostly on the power sector, leaving little space for forestry actions, particularly in developing countries. This misrecognition is related to a strong focus on mitigation in industrialised countries. Three main reasons led to this shift and the subsequent creation of REDD+: first, the recognition that at least 17 per cent of total annual greenhouse gas (GHG) (such as $\mathrm{CO}_{2}$, $\mathrm{N}_{2} \mathrm{O}$ or $\mathrm{CH}_{4}$ ) emissions that contribute to climate change come from deforestation (IPCC 2007); second, the fact that REDD+ was seen as a costeffective option to mitigate GHG emissions (Stern 2009); and third, changes in this sense are related to the UNFCCC's guiding principle of 'common but differentiated responsibilities'.

In 2005, Costa Rica and Papua New Guinea argued that the large contribution of deforestation activities in developing countries to global GHG emissions should be recognised and dis-incentivised. These two countries were supported by eight other parties in proposing a mechanism for Reducing Emissions from Deforestation (RED) in developing countries (Parker and Mitchell 2009: 12). A two-year process was then started to explore options for this mechanism begun through submission of proposals and recommendations to the Subsidiary Body on Scientific and Technical Advice (SBSTA) under the UNFGCG (Parker and Mitchell 2009).

This was followed by the inclusion of Reducing Emissions from Deforestation and Forest Degradation (REDD) as part of national/ international action on mitigation of climate change in the UNFGCG Bali Action Plan of 2007. REDD also recognised the role of conservation, sustainable management of forests and enhancement of forest carbon stocks in developing countries (UNFCGC 2007: 1-2). In 2008, several countries including India argued that REDD should imply embracing all different activities proposed in the draft negotiating text (Holloway and Giandomenico 2009), later referred to as REDD+ in the Copenhagen Accord (UNFCGC 2009). These additional + measures were to avoid creating incentives for countries whose deforestation rates remained very high, while rewarding those whose forest cover is more protected due to conservation and sustainable management (Thompson et al. 2011).

Despite agreement on the recognition of REDD+ as a key mitigation mechanism, there have been three major contentious issues around negotiations over REDD+, namely:

- The inclusion of environmental and social co-benefits, including improving community 


\section{Box 1 Financial mechanisms in REDD+}

The Copenhagen Accord of 2009 and subsequent Cancun agreement of 2011 stated that a Green Climate Fund will be established and will work as an operating entity of the financial mechanism of the Convention in order to support initiatives in developing countries related to mitigation, including REDD+ (UNFCGC 2009: 7). Discussions surrounding financing moved towards a hybrid model that includes both marked-based mechanisms, as well as voluntary donations as sources of funding. Parties and observers are therefore considering different options for funding, including direct carbon market funding (where buyers pay sellers for an environmental service such as REDD+), market-linked funding (where revenues are generated from auctions of emissions), voluntary funds and debt-for nature swaps (Parker and Mitchell 2009; Wertz-Kanounnikoff and Angelsen 2009).

livelihoods, conserving biodiversity, governance and rights, poverty reduction, climate change adaptation and protecting water resources (Verchot and Petkova 2009: 22);

- The use of carbon markets as a way of generating financial resources for REDD+ has gained different degrees of support, while it has also been strongly criticised;

- The recognition of indigenous people's and other forest-dwellers' rights in REDD+.

The debate around these three issues reflects conflicting interests among different groups who are involved in spaces for negotiation around climate change such as the UNFCGC. Common to all is a conviction that these participatory fora open up channels for more effective communication and negotiation. However, participation is rarely implemented as a mutual decision-making process (VeneKlasen et al. 2004: $6)$. Thus, REDD+ decision-making processes around the three above-mentioned issues involve trade-offs in one or other direction.

The 2009 COP15 witnessed the inclusion of co-benefits within REDD+ debate, such as improving community livelihoods, conserving biodiversity and protecting water resources (UNFCGC 2009). There remains much divergence on whether and how social and environmental co-benefits should be mandated in the design of the international REDD+ regime. While some actors favour keeping REDD+ simple and not encumbering it with additional requirements, others support a broader approach that ensures community benefits and biodiversity conservation (Verchot and Petkova 2009). At the Bonn UNFCGC meetings in June 2009, the development of measures and safeguards that protect biodiversity was discussed. However, in September 2009 at the seventh session of the Ad
Hoc Working Group for Long-term Cooperative Action (AWG-LCA), against the express wishes of some 20 countries (including Norway, Brazil, Mexico, India and Switzerland), the European Union supported by the Democratic Republic of the Congo speaking for Cameroon, Equatorial Guinea and the Republic of the Congo blocked the inclusion of language to prevent the conversion of natural forests to plantations. As a result, the provision for safeguards was eliminated from the negotiating text (Holloway and Giandomenico 2009). As it can be inferred, actor coalitions are playing a key role in supporting particular agendas, hence intensifying the REDD+ debate. Underlying this divide is the question of whether mitigation should take precedence over other issues such as biodiversity or poverty reduction in REDD+.

As forestry financing has been low and the UNFCGG currently lacks a legally binding framework to protect tropical rainforests, financing has also become one of the main aspects in REDD+ negotiations. In addition, how money will be generated is central, as REDD+ will require substantial investments, estimated to be between US $\$ 17-33$ billion per year (Parker et al. 2009: 19).

In particular, one of the major contentions around REDD+ financing (Box 1) is the use of carbon markets, with the inclusion of REDD+ in a post-2012 climate agreement seeming to support establishment of global carbon forest markets (UN-REDD 2010). Underlying this tension is the issue of property rights governing who owns the carbon and who has the right to benefit from incentives generated from ecosystem services (Verchot and Petkova 2009), with some countries calling for use of markets, including the USA, the European Union and 
Australia (Parker and Mitchell 2009). Private sector and financial institutions suggest the use of carbon markets can be a way of creating incentives for private sector involvement (Kossoy and Ambrosi 2010). On the other hand, Norway and Tuvalu have both recommended that a decision on whether or not to link REDD+ to carbon trading be postponed (Holloway and Giandomenico 2009).

It is argued that the use of carbon markets may lead to the dispossession of forest-dwellers that rely on forests for food and energy insecurity. Therefore, there is growing recognition on the need to involve them in REDD+ decision-making processes (Steni 2010). Protection of the rights of indigenous peoples and local communities has nonetheless been one of the major areas of contention in the REDD+ negotiations; tensions which can be situated in the context of previous negotiations on the United Nations Declaration on the Rights of Indigenous Peoples (UNDRIP) (Menotti et al. 2008). At the COP14 UNFGCG meetings in December 2008, the USA, Canada, New Zealand and Australia blocked the inclusion of reference to 'indigenous peoples' and the explicit mention of rights (Holloway and Giandomenico 2009: 14). In particular, there has not been agreement on the inclusion of free, prior and informed consent (FPIC) in REDD+ (Brown et al. 2008). FPIC refers to no coercion, intimidation or manipulation of indigenous peoples, looking for consent before the authorisation or commencement of activities and providing information to them (UN 2007).

As a result, although the Copenhagen Accord stresses the need for full and effective engagement of indigenous peoples and local communities in REDD+, the rights of forest communities in REDD+ have not been recognised yet in COP agreement (UNFCGC 2009). In Cancun, the AWG-LCA has suggested the establishment of safeguards for REDD+ that respect the knowledge and rights of indigenous peoples and members of local communities, by taking into account UNDRIP (UNFGCG 2010). The results of the AWG-LCA will be presented in COP17 in December 2011.

The history of REDD+ negotiations provides evidence of a governance system where clearly different interests are competing with each other. Material choices are not the only factor hampering the possibility of an agreement on REDD + . While political and financial agendas play a key role in developing the global REDD+ architecture, actors' competition around co-benefits, markets and rights is also being determined by different environmental worldviews.

\section{Ideological drivers in the development of REDD+}

To date, 33 governmental and non-governmental proposals have been submitted on different methodologies and approaches to REDD+ (Parker and Mitchell 2009). There are a number of competing narratives and framings around REDD +. System framings not only involve objective choices but also subjective values. These framings often become part of narratives that are supported by particular actors, networks and institutions and justify a particular set of actions (Leach et al. 2010). We argue here that REDD+ proposals can be linked to four main environmental worldviews that link forests and development (following Clapp and Dauvergne 2005).

\subsection{Forests and economic growth: the market-liberal approach}

Underpinning this ideology is the idea that economic growth and high per capita incomes are essential for human welfare and the maintenance of sustainable development. Market is ultimately the fairest distributor of benefits because its efficiency leads to maximising of overall welfare (Cazorla and Toman 2000). When it comes to forests, this approach has produced two different discourses. The first is that forest products are a great source of economic growth and poverty reduction within developing countries (World Bank 2002). This is reflected in the vision of the Indonesian government in 1990 of the contribution of forests to development:

The logging industry is a champion of sorts... It creates the necessary conditions for social and economic development. Without forest concessions most of the Outer Islands would still be underdeveloped.

(Ministry of Forestry quoted in Gellert 2005: 1351)

International and national pressure on the recognition of negative consequences of deforestation and forest degradation, especially in the context of climate change, produced a shift towards the inclusion of environmental conservation in the market-liberal approach 
(Rudel 2008; Stern 2009). This is characterised by the 'double dividend' that can 'help the environment without hurting the economy' (Bosquet 2000: 19). From this perspective, environmental conservation should foster market equilibrium and not produce economic distortions, emphasising cost-efficiency over equity (Gellert 2005). This ideology is illustrated by logging companies such as the Asia Pulp Paper company in Indonesia, who are using REDD+ as part of their corporate social responsibility strategy (APP 2010). This second version of the market-liberal approach has led to the creation of companies that manage investments in sustainable forestry, such as New Forests and Keep the Habitat (KTH), two Australian companies currently working on REDD+ in Indonesia. The managing director of $\mathrm{KTH}$ explained their interests in REDD+ as follows:

The underlying principle for REDD+ projects is sustainable forestry so we are working with concession holders in Sulawesi Barat. We are working through with investors into the rehabilitation side... They are interested in REDD + because with the regulation we have in Indonesia their investment will generate a financial return on the timber industry. In addition, they get a revenue on the carbon... they assess it as a profitable investment, we call it the business of conservation.

(Turvey pers. comm.)

According to the World Bank, increased private sector involvement and the use of carbon markets are seen as essential options for future sustainability of REDD+ mechanisms:

the magnitude of finances required for REDD+ (on the order of billions of dollars per year) requires the involvement of the private sector. Official development assistance alone will not be able to carry the weight. The question is therefore what will motivate the private sector to contribute to scale. The carbon market could provide one of these incentives. (Kossoy and Ambrosi 2010: 34)

\subsection{Forests and governance: institutionalists}

This ideology centres on the need for strong institutions, good governance and effective laws to protect the environment and human wellbeing. Key barriers for good governance include flawed policy and legal framework, minimal enforcement capacity, insufficient data, corruption and market conditions for wood products (ITTO and FAO 2009; FCP 2009; EU-FLEGT 2011). This perspective drives the belief that market access for timber, and in the future for other commodities that drive deforestation (such as palm oil, beef, soy, leather) may be a more powerful driver or incentive for improving governance than orthodox international aid to developing countries to finance capacity building.

This ideology is also reflected in the proposed good governance in the phased-approach to REDD+ supported by the World Bank Forest Carbon Partnership Facility (FCPF) and the United Nations UN-REDD+ programme. In these programmes, developing countries are assisted in laying out and organising the steps needed to achieve 'readiness' for REDD+ (FCPF 2009). The UN frames governance differently from the World Bank however, in that it includes the 'respect for the knowledge and rights of Indigenous Peoples and members of local communities' as a key issue in REDD+ governance (UN-REDD 2010). The institutional approach has also been supported by institutions such as UN-REDD and the World Bank-led FCPF through the 'readiness mechanisms'. Both are key players in REDD+, with the FCPF currently working within 37 countries and contributing more than US\$180 million (Sierra 2010) and UN-REDD being involved in 27 countries and contributing US $\$ 92$ million (UN-REDD 2011).

Capacity-building and the focus on governance become even more relevant in the context of the recent inclusion of REDD+ within Nationally Appropriate Mitigation Actions (NAMAs) under the UNFCCC, where governments play a key role in mitigation actions (UNFCGC 2011b). On the other hand, the institutionalist approach may also lead to a predominantly market-liberal discourse and a government vacuum in some cases (Clapp and Dauvergne 2005). For instance, the FCPF states that 'local government eligibility to participate in REDD+ will be conditional on meeting specific standards and indicators of good governance' (FCPF 2009).

\subsection{The ecological value of forests: 'bio-environmentalists'}

This environment worldview is led by the narrative that the Earth is seen as a fragile ecosystem which can support life but only to a certain limit. For instance, campaign groups argue 
that 350 parts per million $\mathrm{CO}_{2}$ in the atmosphere is the safe limit for humanity and that this should be the basis of international climate change negotiations (350 2010). Since natural resources are also finite for bio-environmentalists, economic growth and population growth are incompatible with environmental sustainability. From this perspective, human behaviour needs to be modified in order to solve global environmental problems (Clapp and Dauvergne 2005).

First, this narrative seeks to push the climate change agenda towards ambitious emission reduction targets, as well as drastic changes in deforestation rates. For example, the World Wildlife Fund for Nature (WWF) is proposing an emission reduction target of at least 75 per cent by 2020 , with a view to eliminating nearly all human-induced forest emissions by 2030 (WWF 2009). Greenpeace has stated that the Brazilian government should 'adopt ambitious deforestation reduction targets in order to achieve zero deforestation in the Brazilian Amazon by 2015 and to adopt a five-year moratorium immediately on deforestation as an intermediate step towards zero deforestation' (Greenpeace 2009). In addition, advocates of this worldview, such as the environmental NGO Fauna and Flora International highlight the role of forests in biodiversity conservation and in the provision of other environmental services and the need to ensure the presence of these two criteria in REDD+ implementation (FFI 2010).

While the bio-environmentalists are opposed to the business-as-usual model, their vision is not incompatible with the new version of the marketliberal approach. In fact, they may see carbon markets as a means for achieving greater environmental sustainability. For instance, Greenpeace proposes the creation of the Tropical Deforestation Emissions Reduction Mechanism (TDERM), which is a hybrid market-linked fund model for REDD+ (Parker and Mitchell 2009).

\subsection{Social greens}

Social greens believe environment and society cannot be regarded as separate issues (Clapp and Dauvergne 2005). REDD+ is therefore not only about mitigating climate change, as forests are part of the culture and are essential for the wellbeing of forest communities. Social greens' focus has been on indigenous and forest community rights and knowledge and see that this improvement can have positive aspects on the environment (Fairhead and Leach 1997; IIPFCG 2009). For example, in its submission to the SBSTA, the international environmental organisation, Friends of the Earth International (FOEI), stated that:

ensuring Indigenous Peoples' and local communities' rights and interests in the design of REDD is beyond a matter of state obligation. A rights-based approach will also contribute to effectiveness and permanence of REDD programmes. (FOEI 2009)

This approach also highlights the importance of forests as a source of biodiversity and the role of community participation in environmental conservation with alternative actions such as participatory forestry management (Sunderlin and Atmadja 2009; Steni 2010). According to the director of the Indonesian indigenous organisation AMAN:

Indigenous Peoples are the guardians of forests, lands and water management, they have proven to be able to maintain and manage the natural resources. (Setra 2010)

\subsection{The convergence between narratives and actor coalitions?}

While there is a tendency among some groups to advocate for a specific narrative, assumptions on a linear correspondence between actors and narrative may be incorrect. Indigenous organisations are often seen as a homogenous group, but their views vary depending on the organisation, country or region. According to the Interethnic Association of the Development in the Peruvian Rainforest (AIDESEP 2010):

compensation markets of carbon and other polluting emissions have failed because GHG emissions have not decreased from 1900 to 2007, but they have augmented in 11.2 per cent within 'developed' countries... REDD cannot become a carbon market negotiated at the stock exchange masking the global climate criminality.

On the other hand, the Coordinating Body for the Indigenous Organisations in the Brazilian Amazon (COIAB 2008) did not argue against the use of carbon markets and considered the existence of private sector initiatives in REDD+: 
the UNFGGG should guarantee the effective participation of Indigenous Peoples and Traditional Communities in the construction of mechanisms like REDD. However, this participation should be broadened in the pilot projects implemented by governments and private initiatives.

This disjunction between actors and narratives is also evident among Annex-I parties. Unlike other REDD+ country donors such as Australia and the USA, the Norwegian government has taken a line in-keeping with the social green worldview in suggesting 'REDD should secure the rights and involvement of local communities and indigenous peoples' (Parker and Mitchell 2009: 43). As it can be inferred from above, tensions also arise within actor coalitions as those between the World Bank FCPF and the UN-REDD programme, which proposes a human rights-based approach to programming (UN-REDD 2010).

These dynamics of interaction dilute the line linking between actors and narratives, hence suggesting a much more diffuse picture of REDD+ governance that will have clear implications on REDD+ implementation.

\section{Concluding remarks: REDD+ post-2012}

What is the future for REDD+ in a post-2012 global climate change agreement in terms of governance, equity and social justice? The political economy analysis in this article suggests that future REDD+ decision-making processes are likely to be complex, as they are part of a decentralised, power-embedded network where diverse interests, narratives and actors converge (Peskett and Brockhaus 2009).

In this convergence, one can observe that science and path dependency were important drivers in these ideational power configurations.

Indigenous knowledge was a result in part excluded from the policy process, since knowledge about REDD+ has been mainly generated by research institutions related to natural sciences and economics. The uncertainty and risks related to climate change have led to a political demand for rational and objective knowledge conferring natural sciences and economics greater credibility and productive power in REDD+ conceptualisation (Berkhout et al. 2003; Jones et al. 2008). On the other hand, non-science-based narratives such as indigenous knowledge have less power to frame the REDD+ concept. Second, given the historical exclusion of forest peoples from environmental policymaking, the social green narrative is in a disadvantageous position compared to the market-liberal and institutionalist approaches (Sikor et al. 2010). This is reflected in 75 per cent of REDD+ proposals to date, in which 50 per cent advocate the use of markets for funding and 25 per cent the use of hybrid/market-linked mechanisms to fund REDD+ (Parker and Mitchell 2009). This great support of market mechanisms can also be related to Annex I country concerns about the need to find low-cost REDD+ funding mechanisms (Peskett and Brockhaus 2009).

Despite donors' support for the rights of indigenous peoples and other forest-dwellers, to date there is no agreement at the UNFCCG that supports their rights in REDD+. REDD+ decision- making processes are not only a manifestation of historical power relations but are also related to those spaces where REDD+ negotiations happen and to the different ways in which power is materialised (VeneKlasen and Miller 2002; Gaventa 2006). In closed spaces, such as the Conference of Parties or other bilateral negotiations for REDD+, experts and bureaucrats make decisions without necessarily broader consultation or involvement (Gaventa 2006). As the indigenous organisation AMAN puts it:

Actually we are not involved in the negotiations. Of course, as an advocacy group, we try to intervene on both sides. We are not talking in the negotiations, because it's not our negotiations. It's the Norwegian government and the Indonesian government negotiating. (AMAN, in Lang 2010)

The way power is used in these spaces is and will be crucial in the prevalence of some narratives over others in the future global REDD+ architecture. Understanding the ways in which different environmental worldviews in REDD+ exercise power will be crucial to negotiating a global system that balances equity, effectiveness and efficiency. This will mean balancing the need to guarantee indigenous rights and FPIC with the development of REDD+ as an economic opportunity, and the development of legal and institutional regimes at national as well as international level. 
Crucially, establishing national regulations and institutional architecture that recognises and engages local communities and enables benefit streams to reach them will be crucial. This will mean addressing issues of procedural justice in representing diverse voices in REDD+ debates, but also barriers (for more on national REDD+

\section{References}

350 (2010) What is 350? Mission, www.350.org/mission (accessed 5 August 2010)

AIDESEP (National Organization of the Amazon Indigenous People of Peru) (2010) AIDESEP, a Través de Pronunciamiento Público, Sostiene que Proyecto REDD debe Reestructurarse Totalmente, www.aidesep.org.pe/index.php? $\operatorname{codnota}=1392$ (accessed 20 July 2010)

Angelsen A. and Atmadja S. (2008) 'What is this Book About?', in A. Angelsen (ed.), Moving Ahead with REDD: Issues, Options and Implications, Bogor Barat, Indonesia: Center for International Forestry Research (CIFOR)

APP (2010) Corporate Social Responsibility, www.asiapulppaper.com/ (accessed 2 July 2010)

Berkhout, F.; Leach, M. and Scoones, I. (2003) Negotiating Change: Advances in Environmental Social Science, Cheltenham: Edward Elgar

Bosquet B. (2000) 'Environmental Tax Reform: Does it Work? A Survey of the Empirical Evidence', Ecological Economics 34.1: 19-32

Bourdieu, P. (1986) 'The Forms of Capital', in J. Richardson (ed.), Handbook of Theory and Research for the Sociology of Education, New York: Greenwood

Brown, D.; Seymour, F. and Peskett, L. (2008) 'How do we Achieve REDD Co-benefits and Avoid doing Harm?', in A. Angelsen (ed.), Moving Ahead with REDD: Issues, Options and Implications, Bogor Barat, Indonesia: Center for International Forestry Research (CIFOR)

Cazorla, M. and Toman, M. (2000) 'International Equity and Climate Change Policy', Climate Issue Brief 27, Washington: Resources for the Future, www.rff.org/rff/Documents/RFFCCIB-27.pdf (accessed 10 January 2011)

Clapp, J. and Dauvergne, P. (2005) Paths to a Green World: The Political Economy of the Global Environment, Cambridge, MA: MIT Press

Coordinator of Indigenous Organizations of the Amazon Basin (COIAB) (2008) Mudanças Climáticas e Povos da Floresta: Avançando a Discussão em Redução de Emissões por Desmatamento e Degradação Florestal (REDD) e Direitos dos Povos political economy see Shankland and Hasenclever, this IDS Bulletin). Drawing on this approach we suggest that increased institutional support to less powerful forest voices is needed if equity, rights as social justice are to be considered as key aspects of the future global climate change regime.

Indígenas e Tradicionais. Declaraçao de Manaus, www.coiab.com.br/coiab.php?dest $=$ show $\&$ back $=$ noticia\&id $=60 \&$ tipo $=\mathrm{N} \&$ pagina $=30$ (accessed 13 July 2010)

Fairhead, J. and Leach, M. (1997) 'Webs of Power and the Construction of Environmental Policy Problems: Forest Loss in Guinea', in R.D. Grillo and R.L. Stirrat (eds), Discourses of Development: Anthropological Perspectives, London: University College London

EU-FLEGT (2011) 'What is REDD+?' FLEGTREDD + Linkages, Briefing Note 2, Brussels: Proforest, www.euflegt.efi.int/files/attachments/ euflegt/flegt_redd_bn_2_web.pdf (accessed 10 January 2011)

FCP (2009) Indonesia-Australia Forest Carbon Partnership Factsheet, www.ausaid.gov.au/hottopics/ pdf/IAFCP_factsheet_2_11Dec09.pdf (accessed 20 July $201 \overline{0}$ )

FCPF (2009) Indonesia R-Plan: Synthesis Review by FCPF Technical Advisory Panel, www.forestcarbonpartnership.org/fcp/sites/ forestcarbonpartnership.org/files/Documents/ PDF/Indonesia_R-Plan_TAP_synthesis_06-209.pdf (accessed 4 August 2010)

FFI (2010) 'Why Biodiversity Matters for Carbon Storage', FFI Briefing, www.fauna-flora.org/ docs/FFI-briefing-Why-biodiversity-mattersfor-carbon-storage.pdf (accessed 28 July 2010)

Friends of the Earth International (FOEI) (2009) Views on Issues Relating to Indigenous Peoples and Local Communities for the Development and Application of Methodologies, http://unfccc.int/ resource/docs/2009/smsn/ngo/105.pdf (accessed 23 July 2010)

Gaventa J. (2006) 'Finding the Spaces for Change', IDS Bulletin 37.6: 23-33

Gellert, P.K. (2005) 'The Shifting Natures of "Development": Growth, Crisis, and Recovery in Indonesia's Forests', World Development 33.8: 1345-64

Greenpeace (2009) Amazon Cattle Footprint. Mato Grosso: State of Destruction, www.greenpeace.org/ raw/content/international/press/reports/ amazon-cattle-footprint-mato.pdf (accessed 25 August 2010) 
Holloway, V. and Giandomenico, E. (2009) Carbon Planet White Paper: The History of REDD Carbon Policy, Adelaide: Carbon Planet Ltd

International Indigenous Peoples Forum on Climate Change (IIPFCG) (2009) http://unfccc.int/resource/docs/2009/smsn/ ngo/108.pdf (accessed 16 July 2010)

IPCC (2007) Climate Change 2007: Synthesis Report. An Assessment of the Intergovernmental Panel on Climate Change, Cambridge: Cambridge University Press

ITTO and FAO (2009) ITTO Thematic Programme on Forest Law Enforcement, Governance and Trade, Geneva: International Tropical Timber Organisation

Jones, H.; Jones, N.; Walker, D. and Walsh, C. (2008) Political Science? Strengthening Science-policy Dialogue in Developing Countries: A Priority for Climate Change Adaptation, ODI Working Paper 294, London: Overseas Development Institute

Kossoy, A. and Ambrosi, P. (2010) State and Trends of the Carbon Market 2010, http://siteresources.worldbank.org/INTCARB ONFINANCE/Resources/State_and_Trends_ of_the_Carbon_Market_2010_low_res.pdf (accessed 24 July 2010)

Lang, C. (2010) Interview with Abdon Nababan and Mina Setra, www.redd-monitor.org/2010/07/04/ per centE2 per cent 80 per cent 9 Cwe-want-tochange-this-threat-to-an-opportunity per centE2 per cent80 per cent9D-interview/ (accessed 10 August 2010)

Leach, M.; Scoones, I. and Stirling, A. (2010) 'Governing Epidemics in an Age of Complexity: Narratives, Politics and Pathways to Sustainability', Global Environmental Change 20: 369-77

Menotti, V.; Greensfelder, C.; Delman, L.; Damasco, K.; Halbert, A. and MacKnight, N. (2008) Implementing the United Nations Declaration on the Rights of Indigenous Peoples, San Francisco: International Forum on Globalisation and TEBTEBBA Foundation

Parker, C. and Mitchell, A. (2009) The Little REDD + Book: A Guide to Governmental and Nongovernmental Proposals for Reducing Emissions from Deforestation and Forest Degradation, Oxford: Global Canopy Programme

Parker, C.; Brown, J.; Pickering, J.R.E.; Mardas, N. and Mitchell, A.W. (2009) The Little Climate Finance Book, Oxford: Global Canopy Programme

Peskett, L. and Brockhaus, M. (2009) 'When REDD+ Goes National: A Review of Realities, Opportunities and Challenges', in A.
Angelsen (ed.), Realising REDD +. National Strategy and Policy Options, Bogor Barat, Indonesia: Center for International Forestry Research (CIFOR)

Rudel, T.K. (2008) 'Changing Agents of Deforestation: From State-initiated to Enterprise-driven Processes, 1970-2000', Land Use Policy 24: 35-41

Santilli, M.; Moutinho, P.; Schwartzman, S.; Nepstad, D.; Gurran, L. and Nobre, C. (2005) 'Tropical Deforestation and the Kyoto Protocol: An Editorial Essay', Climatic Change 71.3: 267-76

Setra, M.S. (2010) 'Indigenous Peoples and their Traditional Forest Management System: Effective Roles of Traditional Knowledge in REDD+', PowerPoint presentation at the Side Event, Bonn

Sierra, K. (2010) Welcome Note from the FCPF Chair, www.forestcarbonpartnership.org/ fcp/node/17 (accessed 8 August 2010)

Sikor, T.; Stahl, J.; Enters, T.; Ribot, J.C.; Singh, N.; Sunderlin, W.D. and Wollenberg, L. (2010) 'REDD-plus, Forest People's Rights and Nested Climate Governance', Global Environmental Change 20.3: 423-25

Steni, B. (2010) 'Better Governance in the Forestry Sector or Business as Usual?', in Edward Fenton (ed.), Realising Rights, Protecting Forests: An Alternative Vision for Reducing Deforestation. Case studies from the Accra Caucus, www.careclimatechange.org/files/reports/ Accra_Report_English.pdf (accessed 29 March 2011)

Stern, N. (2009) A Blueprint for a Safer Planet: How to Manage Climate Change and Create a New Era of Progress and Prosperity, London: The Bodley Head Sunderlin, W.D. and Atmadja, S. (2009) 'Is REDD+ an Idea whose Time has Come or Gone?', in A. Angelsen (ed.), Realising REDD +. National Strategy and Policy Options, Bogor Barat, Indonesia: Center for International Forestry Research (CIFOR)

Thompson, M.C.; Baruah, M. and Carr, E.R. (2011) 'Seeing REDD+ as a Project of Environmental Governance', Environmental Science and Policy, in press

UN (2007) United Nations Declaration on the Rights of Indigenous Peoples, www.un.org/esa/socdev/ unpfii/en/drip.html (accessed 5 July 2010)

UNFCGC (2011a) Convention Bodies, http://unfccc.int/essential_background/ convention/convention_bodies/items/2629.php (accessed 21 January 20-11) 
UNFCGG (2011b) Nationally Appropriate Mitigation Actions of Developing Country Parties, http://unfccc.int/home/items/5265.php (accessed 21 January 2011)

UNFGGG (2010) Outcome of the Work of the Ad Hoc Working Group on Long-term Cooperative Action under the Convention http://unfccc.int/files/ meetings/cop_16/application/pdf/cop16_lca.pdf (accessed 10 January 2011)

UNFGGG (2009) Copenhagen Accord, http://unfccc.int/resource/docs/2009/cop15/ eng/1 1a01.pdf (accessed 12 July 2010)

UNFGCG (2007) Bali Action Plan, http://unfccc.int/files/meetings/cop_13/ application/pdf/cp_bali_action.pdf (accessed 3 July 2010)

UNFGCG (1997) Kyoto Protocol to the United Nations Framework Convention on Climate Change, http://unfccc.int/resource/docs/convkp/ kpeng.pdf (accessed 5 July 2010)

UN-REDD (2011) UN-REDD Countries at a Glance, www.un-redd.org/AboutUNREDDProgramme/ NationalProgrammes/tabid/584/Default.aspx (accessed 15 January 2011)

UN-REDD (2010) 'Monitoring Safeguards for REDD+', UN-REDD Newsletter 9, www.un-redd.org/Newsletter9_Monitoring_ Governance_Safeguards/tabid/4661/language/ en-US/Default.aspx (accessed 18 July 2010)
VeneKlasen L. and Miller V. (2002) New Weave of Power, People and Politics: The Action Guide for Advocacy and Citizen Participation, Oklahoma: World Neighbors

VeneKlasen, L.; Miller, V.; Clark, C. and Reilly, M. (2004) Rights-based Approaches and Beyond: Challenges of Linking Rights and Participation, IDS Working Paper 235, Brighton: IDS

Verchot, L.V. and Petkova, E. (2009) The State of REDD Negotiations: Consensus Points, Options for Moving Forward and Research Needs to Support the Process. A Background Document for the UN-REDD Programme Sponsored Support to Regional Groups, Bogor Barat, Indonesia: Center for International Forestry Research (CIFOR)

Wertz-Kanounnikoff, S. and Angelsen, A. (2009) 'Global and National REDD+ Architecture: Linking Institutions and Actions', in A. Angelsen (ed.), Realising REDD + at the National Level. National Strategy and Policy Options, Bogor Barat, Indonesia: Center for International Forestry Research (CIFOR) World Bank (2002) Sustaining Forests: A World Bank Strategy, Washington DC: World Bank

WWF (2009) WWF Forest Carbon Initiative: Response to Noel Kempff Climate Action Project, http://wwf.panda.org/what_we_do/footprint/ climate_carbon_energy/forest_climate/news/ ?uNewsid $=17 \overline{4} 442$ (accessed $\overline{2} 3$ July 2010) 